\title{
"If You're Black, Get Back!" The Color Complex: Issues of Skin-Tone Bias in the Workplace
}

\section{Letisha Engracia Cardoso Brown University of Northern Colorado}

Skin-tone has always played a role in the socioeconomic lives of African-Americans, and while there are always successes, there are also those who are not as fortunate. A major success for African Americans has come in the shape of the election of the nation's first AfricanAmerican President, Barack Obama, and, by extension, the first African-American First Lady, Michelle Obama. Among the cries of happiness and hope after the election, there lingers a feeling among many Americans whether Barack Obama would have been elected if he were darker rather than lighter skinned. Though the question is rhetorical at this point the question is nevertheless one asked in many American households. Even after the election and inauguration of the first Black President and the subsequent entrance of the first Black Family into the White House, many critics wonder whether the United 
States is still a nation absorbed in skin-tone prejudices or has, in the words of the late Reverend Martin Luther King Jr., truly "overcome" them. With such a question in mind, the position of the First Lady becomes a precarious one. While she is not principally responsible for guiding the fate of the nation, her role is a visible one, which makes her presence in the public eye an important one nonetheless. Historically, the First Lady is expected to embody ideals of womanhood such as virtue, beauty, grace, and honor to the nation at large. Up until this point, these ideals have been expressed to young women in this nation as coterminous with the concept of "whiteness." More pointedly, will images of beauty shift away from narrow Eurocentric standards because a Black First Family resides in the White House?

One of the factors correlated with perceptions of skin-tone and socioeconomic status is the concept of beauty. Beauty, therefore, is more than a physical representation of aesthetic appeal; it holds a viable position in all aspects of American social life. According to author Margaret L. Hunter, beauty operates as a tool of "social capital" for women (177). As such, if the beauty ideal in this nation has been one centered on Eurocentric appeal, how has it affected the lives of the other racial and ethnic populations within American society? Specifically, how have these attitudes developed into a system of colorism, or skin-tone biases, and how have these attitudes affected the socioeconomic lives of African-American women, specifically and mainly, in the workplace? The most recent data collected concerning the issue of skin-tone bias with socioeconomic status was collected in the mid-1990s, over a decade ago. Since then, there has been a gap in current data collection. Therefore, I intend to determine if there have been any significant changes in the impact of colorism on AfricanAmerican women in the workplace through the process of interviews, qualitative as well as quantitative research, since the last data collection. 
The key concepts that this paper will focus on are as follows: racism, colorism, amalgamation, phenotypic characteristics, hypo-descent, white supremacy, and socioeconomic status. Each is broadly defined as follows: racism in the context of this paper refers to the systematic privilege given to persons of European descent over the rest of the American population; colorism will refer to the systematic privileging of lighter skinned members within a community of color over those of darker complexion; amalgamation will be understood as the process of racial mixing through sexual intercourse; and lastly, phenotypic characteristics will apply to those physical features used as tools for social and political separation, i.e. hair texture, nose shape, lip thickness, etc. Moreover, hypodescent will refer to the legal means of designating mixed race individuals in the category of "lower race," or race of color; white supremacy will refer to the ideology that keeps all of the tools for social separation firmly rooted in American society. For example, more than the actions of members of racist organizations like the Ku Klux Klan. For the purpose of this paper, the term white supremacy will refer to the ideology that keeps the tools for social preparation firmly rooted in American society through a hierarchal ordering of different racial categories, whereby persons of European descent are at the top. Lastly, socioeconomic status refers to three dominant categories: education, income, and marriage.

\section{Literature Review}

\section{Colorism and Gender}

Colorism, as stated earlier, is the American system that privileges the lighter-skinned over the darker-skinned members within a community of color (Gullickson, 2005; Hunter, 2002; Hill, 2002; Ross, 1997; Keith \& Thompson, 2001). Several studies have concluded that skin tone, in most instances, is a more salient factor for women than for men. Furthermore, the authors concluded that 
women with lighter skin tone tend to receive more privilege in the form of socioeconomic gains than darkskinned women with the similar social characteristics (Hunter, 1998; Hunter, 2002; Hunter, 2005). Hill (2002) found that skin tone is a more salient characteristic for women than for men in terms of perceived attractiveness (77). Although it may not seem like a viable factor within the workplace, perceptions of attractiveness does play a quantifiable role in the socioeconomic status of African-American women. Hunter (2002) maintains that attractiveness or beauty can operate as "social capital" for Black women (77). Within a study conducted by Hunter in 2002, it was determined that light-skinned women could use their lightness to increase their socioeconomic status in three dimensions: education, income, and marriage. The findings of the Hunter study found that on average African American women of a lighter-skin tone tend to earn more money, go farther in higher education, and marry men of a higher economic status as compared to darker-skinned counterparts.

In addition, Sekayi (2003) conducted a study indicating that some Black women chose to consiously conform to Eurocentric ideals of beauty as opposed to African standards. This desire for assimilation reinforces the role white supremacist attitudes such as colorism play in contemporary society. Within a community of color, darkskinned women often witness the privilege granted to their lighter skinned counter parts, just as light skinned women witness the privileges granted to White women. In response to these intraracial as well as interracial privileges, Black women, consciously and unconsciously, move towards ideals of beauty connected to perceptions of whiteness (Sekayi, 2003). It is necessary to understand these three basic levels of socioeconomic statuseducation, income, and marriage-as interrelated. Furthermore, within these three levels, color impacts the attainment level negatively or positively as based on perceived skin tone variations. 
For example, Ross conducted a study proposing two major hypotheses: men and women will have different criteria for dating; men will generally illustrate a stronger preference for physical appeal in the form of lighter skin tone than women will (559). Skin tone is a factor when it comes to spousal selection. Based on recent data spousal selection further supports the notion that skin-tone is a more salient factor for women than for men, since the men who responded based their spousal selection preferences on skin tone more than women. Additionally, researchers argue that Black women are more able to use light skin to their socioeconomic advantage than Black men (Hill, 2002; Hunter, 1998; Hunter, 2002; Hunter, 2005; Keith \& Thompson, 2001; Ross, 1997; Sekayi 2003). Whether used as a form of "social capital," (Hunter, 2002) or as a tool for gauging self esteem (Keith \& Thompson, 2001), skin tone is a more salient factor of socioeconomic status for Black women than for Black men.

\section{Qualitative Analysis}

Qualitative research will consist of personal narratives, interviews, and literary works of fiction. All of these methods of data collection will offer a personal account of how color affects the socioeconomic status of Black women in order to expose how skin tone bias impacts women in the workplace. Studies break down socioeconomic status into three principle dimensions-education, income, and marriage (Gullickson, 2005; Henshel, 1971; Hunter, 1998; Hunter, 2002; Hunter, 2005). These dimensions are interrelated since education can be used as a determinant for future income, and income can broaden or narrow a woman's option for marriage. Interviews and personal narratives will be used, furthermore, to show an interrelation between these dimensions. Literary works of fiction will focus primarily on the concept of "beauty," a tool used to achieve socioeconomic gains. For instance, several studies have shown that light skinned women are more likely to marry men of a higher social status than 
dark skinned women with similar credentials (Hunter, 1998; Hunter, 2002; Hunter, 2005).

Toni Morrison's The Bluest Eye illustrates exactly how perceptions of beauty operate as social capital. Morrison's novel is set in 1941 Lorain, Ohio, just at the end of the Depression in the 1930s. The central characters of this novel are the members of the Breedlove family, principally, youngest daughter, Pecola. Like many of the Black families depicted in this novel, the Breedloves are of low income status. However, a factor that sets them apart from the other poor families in the novel, according to the narrator, is their perceived "ugliness," in terms of their physical appearance, as well as their attitudes towards life and the world in which they lived. Within the context of Morrison's novel, Pecola describes her idea of beauty as having white skin and, especially, blue eyes-ideally like Shirley Temple. Throughout the novel Pecola struggles fantastically and impossibly to gain this physical trait which she believes will forever alter her circumstance and fate. As Pecola imagines, if she is "beautiful," her family situation will not be as dire for her as it is. Morrison's work illuminates how deeply color stratification permeates American society. Pecola struggles with a concept of beauty reflected by the white child actress Shirley Temple, which, as a young black girl, is her exact aesthetic opposite. When the epitome of beauty does not resemble you at all, as Morrison's novel expresses, it is difficult to cope and find understanding and self-acceptance.

Another fictional representation of race is Zora Neale Hurston's novel Their Eyes Were Watching God, which was set mostly in the all black town of Eatonville, Florida. In this novel, the character Janie proclaims: "Ah jus couldn't see mahself married to no black man. It's too many black folks already. We ought to lighten up the race" (3). This is another example of how colorism operates within the Black community. These fictional illustrations are not limited to imaginative works of 
literature though; in some cases, they represent the feelings of many African Americans during the era in which the authors were writing as well as those held by African Americans today. In the memoir Don't Play in the Sun: One Woman's Journey through the Color Complex, Marita Golden describes a scene from her life that echoes the words of Hurston's character:

One summer afternoon when I am playing outside, racing the boys on our street to see who can reach the end of the block first (l do), my mother comes onto the porch and as I speed past shouts out to me, "Come on in the house-its too hot to be playing out here. I've told you don't play in the sun. You're going to have to get a light skinned husband for the sake of your children as it is (4).

Moreover, white supremacist attitudes and systematic racism help explain the manifold social inequalities in most Western societies (Christian, 2002). All levels of social interaction are therefore interwoven, since ideology, as it permeates one level of society like the personal, will often seep through to other levels as well, as it does the professional. The relationship people of color have with racial attitudes and perceptions is reflected in all aspects of society, making the separation between the personal and the professional difficult to discern. In an interview conducted by Margaret L. Hunter, a dark skinned woman explains how skin tone affected her relationship with a light skinned friend:

Color has always come up in my life. Always. It's bad to be dark. It's good to be light when I was growing up. I will say that I started to resent lighter skinned women. I have a friend of mine [who is light skinned]. When I lived next door to her, I hated her. She's beautiful. And I thought: "God, I hate you." I never talked to her because she was beautiful. But, [skin] 
color has always come up. It's like how in slavery times the lighter person would be up in the house. That's still going on because lighter is closer to white, and since it's closer to white, its better (73).

This is an example of how skin tone bias affects people in their personal relationships, which they then can carry over into their workplace relationships.

\section{Quantitative Research}

The general hypothesis of the quantitative data to be reviewed is how skin tone affects Black women in the workplace negatively within increasing gradients of skin color (Gullickson 2005; Hunter, 1998; Hunter, 2002; Hunter, 2005; Ross, 1997). Furthermore, aesthetic appeal for Black women will diminish as darkness increases (Keith \& Thompson, 2001; Ross, 1997; Sekayi, 2003). Longitudinal data gleaned from the Panel Study of Income Dynamics $(1975,1976)$ offered information on how sex and gender affect the amount of authority people hold in the workplace. Authority is a concept directly related to professional environments and will be defined as the "probability that a command with a given specific content will be obeyed by a given group of person..." (Smith, $2002,510)$. The cross sectional data that was obtained showed that "race (and sex) differences in earning are partly due to differential access to span control and span of responsibility; and class and/or authority will have a substantial effect on the earnings net of human capital and labor market characteristics" (Smith, 2002, 528).

Although the research findings above do not account for color stratification per se, they do illustrate how the amount of authority, as well as income, an individual can acquire will decrease or increase according to race and gender differentials. Studies that account for changes across color gradients (Hunter, 1998; Hunter, 2002; Hunter, 2005) explore the relationship between skin tone and authority. In Hunter's (2005) study of the 
socioeconomic status of Black women, a color gradient of 1-5 (darkest to lightest) was used. From that data it was deduced that with each increasing increment of lightness income increased by $\$ 673$ annually (43). Two similar studies by Hunter conducted in 1998 and 2002 gleaned similar results.

In terms of attractiveness and self-concept, the results gathered maintained that perceived "lightness" offered a privileged status to people within a community of color. A 33-question survey conducted by Sekayi (2003) concluded that $46 \%$ of respondent's desired smaller bodies, $32 \%$ were ambivalent or displeased with the texture of their hair, and $26 \%$ disliked their overall appearance (475). These findings are significant for two reasons: 1) they reinforce the dominance of white supremacist ideals, and 2) they enforce the idea that Black women are aware that a Eurocentric aesthetic ideal is more favorable to socioeconomic status. In terms of mate selection, which relates to the socioeconomic component of marriage, light skin is effectively used as social capital. Ross (1997) concluded that 33\% of the men preferred to date women with lighter skin as compared to $16.4 \%$ of women who preferred men with light skin (565). Moreover, $38.3 \%$ of men expressed a desire to marry a woman with a lighter complexion (565). These results reinforce the principle that skin tone, in terms of perceptions of attractiveness, is a more salient factor for women that for men (Keith \& Thompson, 2001; Ross, 1997). As a whole, the quantitative data provided statistical evidence of the impact skin tone plays in the socioeconomic lives of Black women. Furthermore, it offered concrete evidence of the role race and gender play in the workplace beyond the categories of income and hiring rates by showing how it affects levels of authority.

\section{Methodology}

For my study of the impact of skin tone on the socioeconomic status of African-American women today, $I$ intend to interview four African-American women 
within the fields of law and academia. I choose these two particular fields because of the low representation of African-American women within their ranks and my own personal interest. Moreover, the most recent data collected on the subject of skin-tone in regards to African American women are primarily surveys that were conducted in the late 1990s. My data will be obtained from two professors at a middle-sized University in the United States, two lawyers, practicing in a metropolitan area. Fortunately, I was acquainted with all of my participants before I began my research, so locating participants was an easy job. I intend to send out a recruitment letter as well as a letter of consent to the participants I am interested in interviewing. I intend to send out six letters in order to reach my ideal sample size of four participants. The women that I have in mind are all from diverse backgrounds and are also of varying shades of skin-tone.

Although no monetary incentives were offered for the interview process, I do intend to give each participant a thank you card upon completion of each interview. Since my project involves human subjects, I had to obtain permission from the Institutional Review Board (IRB), which was summarily granted. My project deals with adult women from a non-vulnerable population so permission was not difficult for me to obtain. Within the next few months, I intend to obtain data from two separate locations. One of these locations will be in a metropolitan area within the United States; the other, a small college town. Along with a recruitment letter and a letter of consent, I introduced my participants to my project and offered details of my procedures. There will be two interviews approximately an hour each in which a series of questions will be asked and tape recorded. My research advisor and I will be the only ones with access to these interviews once they have been recorded. Afterwards, I will transcribe the information given, and provide each participant with a pseudonym in order to 
insure and maintain confidentiality.

Once I have collected and transcribed the data, I intend to search for trends and patterns in order to determine if there have been significant changes since data was collected in the 1990s. The data collected via surveys in the 1990s showed a significant difference between the socioeconomic attainment of African-Americans with darker and lighter skin, as it showed that those with a lighter complexion achieved higher attainment. I have created approximately 20 questions for my interview sessions; however, my participants will be encouraged to go off on their own and elaborate on a particular theme they wish to identify, although I will work to maintain a proper course. A few of the questions I intend to ask are as follows:

- How do you feel about the color of your skin?

- When did you decided to become a professor/lawyer/ magistrate?

- Who influenced you?

- Have you ever tried to lighten/darken your skin?

- Do you feel that your income is impacted by your skintone?

These are just a few examples of the course that I want my interviews to take. It is my purpose to uncover trends and patterns in order to identify if there have been significant changes since the 1990s. Throughout the course of these interviews, I intend to uncover points in which these women began to view skin-tone as a hindrance to their socioeconomic status. I will look to see how skin tone impacted decisions they made in terms of their careers and personal lives. More specifically, I plan to obtain information on whether or not skin tone impacted their decisions to choose their current profession, and how it plays a role in the fields they now occupy. 


\section{Works Cited}

Christian, M. (2002, November). An African-centered perspective on white supremacy. Journal of Black Studies, 33(2), 179-198.

Golden, M. (2004). Don't Play in the Sun: One Woman's Journey through the Color Complex. New York: Doubleday.

Gullickson, A. (2005). The significance of color declines: A re-analysis of skin tone differentials in a post-civil rights America. American Journal of Sociology, 84(1), 157-180.

Henshel, R. L. (1971). Ab-ility to alter skin color: Some implications for American society. The American Journal of Sociology, 76(4), 734-742.

Hill, M. E. (2002). Skin color and the perception of attractiveness among African Americans: Does gender make a difference? Social Psychology Quarterly, 65(1), 77-91.

Hunter, M. L. (1998). Colorstruck: Skin color stratification in the lives of African-American women. Sociological Inquiry, 68(4), 517535.

Hunter, M. L. (2002). If you're light you're alright: Light skin as social capital for women of color. Gender and Society, 16(2), 175193.

Hunter, M. L. (2005). Race, Gender, and the Politics of Skin Tone. New York: Routledge: Taylor \& Francis Group.

Hurston, Z. N. (1999). Their Eyes Were Watching God. New York: Harper Collins.

Keith, V. M., \& Thompson, M. S. (2001). The blacker the berry: Gender, skin tone, self-esteem and self-efficacy. Gender and Society, 15(3), 336-357.

Morrison, T. (1972). The Bluest Eye. New York: Washington Square Press. (Original work published 1970).

Ross, L. E. (1997). Mate selection preference among African-American college students. Journal of Black Studies, 27(4), 554-569. 
Ethnic Studies Review Volume 32.2

Sekayi, D. (2003). Aesthetic resistance to commercial influences: The impact of the Eurocentric beauty standard on black college women. The Journal of Negro Education, 72(4), 467-477.

Smedley, A. (1998). "Race" and the construction of human identity. American Anthropologist, 100(3), 690-702.

Smith, R. A. (2002). Race, gender, and authority in the workplace: Theory and research. Annual Review of Sociology, 28, 509542. 